\title{
Birds of the Taltson River Region, N.W.T.
}

\section{by George W. Scotter, Canadian Wildlife Service, Edmonton} and Larry E. Erickson, Fort St. James, B.C.

While engaged in a study of the winter range of barren ground caribou (Rangifer tarandus groenlandicus) in the Taltson River region during 1962 the writers made field notes on the birds observed. The study area is located in the Taltson River region of the Northwest Territories and extends from $60^{\circ} 50^{\prime} \mathrm{N}$. to $62^{\circ} \mathrm{N}$. latitude and from $109^{\circ} \mathrm{W}$.

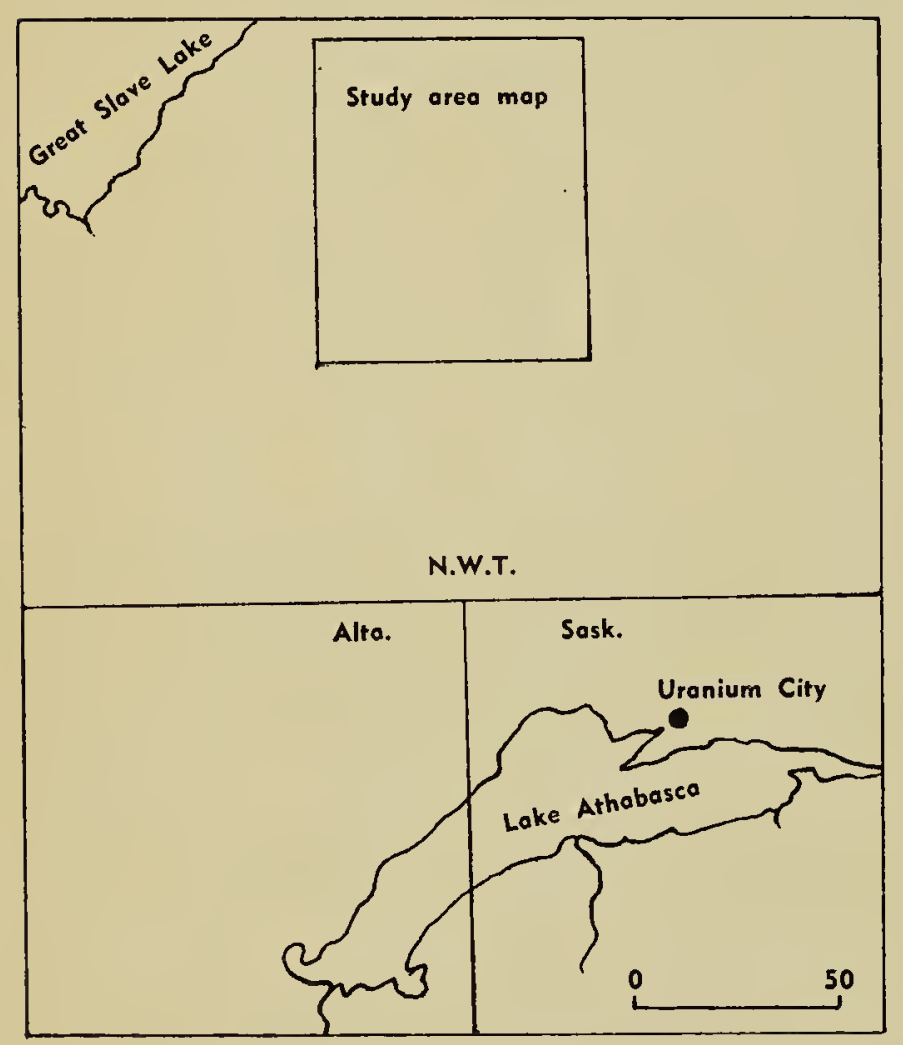

Fig. 1. Location of the Taltson River study area.

to $111^{\circ} \mathrm{W}$. longitude. The study sites and observation periods were as follows: Gagnon Lake (June 22-29), Rutledge Lake (June 30-July 6), Taltson River (South) (July 7-16), Taltson River (North) (July 17-23), Hjalmar Lake (July 24-30), Whirlpool Lake (July 31-August 6), Thekulthili Lake (August 7-17). Figure 1 shows the location of the study area, and figure 2 the study sites in the area.

The forests in the region are dominated by black spruce (Picea mariana) and jack pine (Pinus banksiana). White spruce (Picea glauca) is common on eskers and white birch (Betula payrifera) is found along drainage areas and in some recently burned-over forests. Small clusters of aspen (Populus tremuloides) were found along the bank of the Taltson River.
The physiography of the region has been reported by Camsell (1916). The area has undergone intense glaciation with little glacial deposition. Rocks of the region are reported to be of Precambrian age. The terrain consists of small but rather rugged hills with numerous muskegs and lakes at their bases.

Previous observations of birds in the general area include those by Harper (1931) in the Tazin Highlands to the southwest and those by Scotter (1961) in northern Saskatchewan to the southeast. Unpublished records have been mentioned previously (Scotter, 1961).

The annotated list which follows is doubtless only a partial list of the birds in the region, since other duties precluded more extensive observations. Relative abundance at each study site, along with a few notes of interest, are included. The arrangement and taxonomy is in accordance with the A.O.U. check-list (1957).

\section{ANNOTATED LIST OF SPECIES}

Common Loon Gavia immer

Rutledge L.-common. S. Taltson R.-common. N. Taltson R.-common. Hjalmar L.-fairly common. Whirlpool L.-common. Thekulthili L. -common.

Arctic Loon Gavia arctica

N: Taltson R.-scarce.

Canada Goose Branta canadensis

N. Tatlson R.-scarce. Seven birds were seen near camp on two occasions.

Mallard Anas platyrhynchos

Whirlpool L.-scarce.

Bufflehead Bucephala albeola

Gagnon L.-fairly common, on lake. One nest was found about 8 feet above the ground in a hollow section of a black spruce tree. The tree was located within 6 feet of the lake. S. Taltson R.-rare.

Surf Scoter Melanitta perspicillata Whirlpool L.-fairly common, on islands.

Common Merganser Mergus merganser

Gagnon L.-common, on lake. A nest with 14 eggs was found on a small island. Rutledge L.-common. S. Taltson R.-common. N. Taitson R. -common. Hjalmar L.-common. 


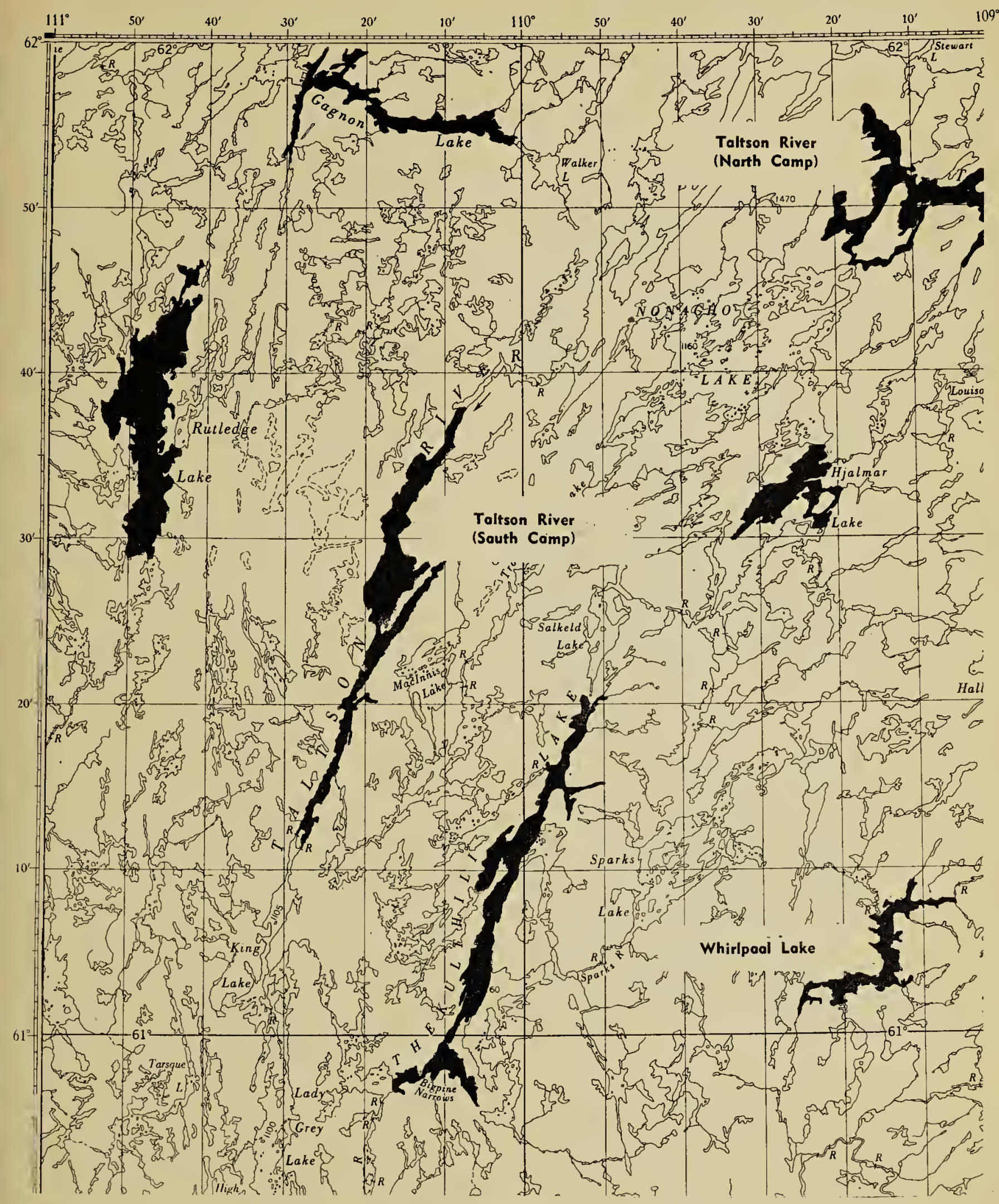

Fig. 2. The darkened areas show the location of the study sites.

Whirlpool L.-common. Thekulthili L.-common.

Goshawk Accipiter gentilis

S. Taltson R.-solitary.

Bald Eagle Haliaeetus leucocephalus Gagnon L.- - three nests, in good condition, were located, but no eagles were seen. Rutledge L.-common on the numerous islands of this lake. Only one young bird was found in the several nests that were examined. S. Taltson R.-14 eagles and several nests were seen in the area. Three eagle nests on the west side of the river, one located 100 yards from our camp and the others approximately 2 miles north and south of the camp, were examined and found empty. Claw marks and freshly scaled bark noted on each tree trunk suggested that some mammal, possibly a wolverine (Gulo luscus), had disturbed the nests. There was, however, no definite proof that eggs or young had been taken. One adult bird was noted almost daily at each of the nest sites during our 10 day interval at this camp. N. Taltson R.-2 birds were seen, but no nests were located. Hjamlar L.-six mature birds were 
seen, as well as one nest which was not in use. Whirlpool L.-only two birds were seen. Thekulthili L.four eagles were observed.

Sparrow Hawk Falco sparverius

Thekulthili L.-fairly common, in recently burned forests.

Spruce Grouse Canachites canadensis

Gagnon L.-common, in mature black spruce forests. Rutledge L.common. S. Taltson R.-common. N. Taltson R.-common. Hjalmar L.common. Whirlpool L.-common. Thekulthili L.-abundant, in mature black spruce forests.

Semipalmated Plover Charadirius semipalmatus

N. Taltson R.-fairly common, on sandy beaches. Hjalmar L.-fairly

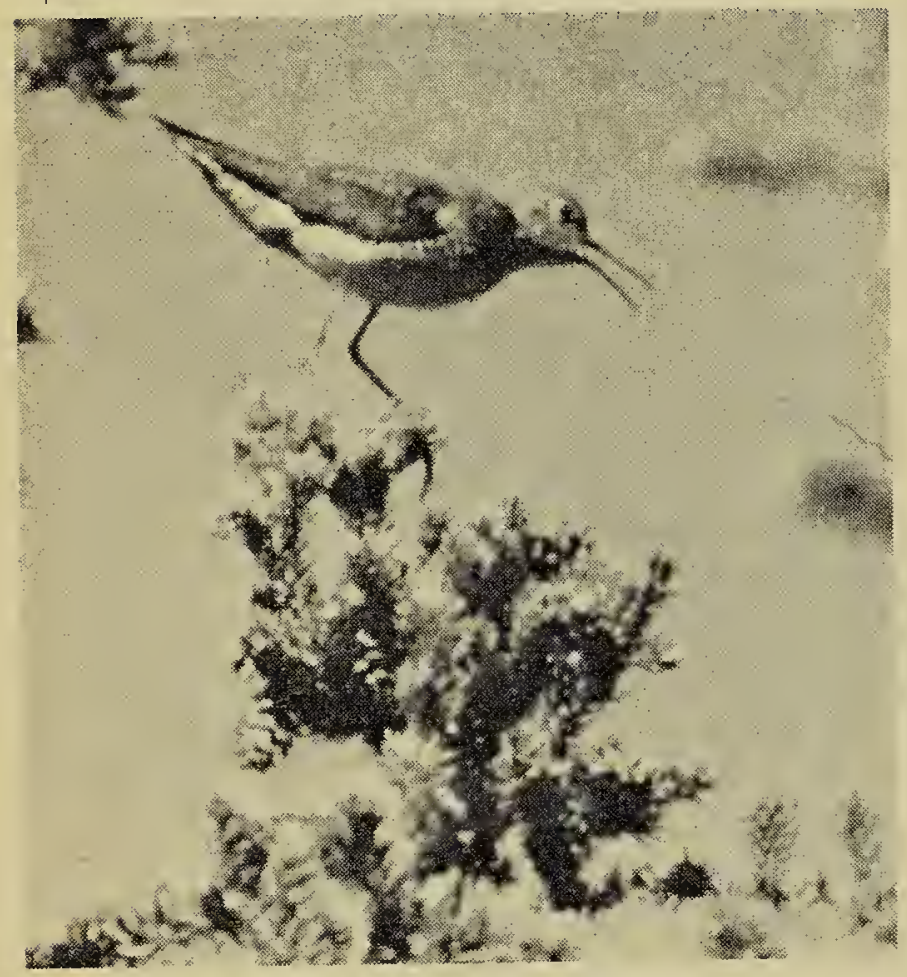

Lesser Yellowlegs

common. Two young were observed daily near our campsite. Whirlpool L.-rare.

Spotted Sandpiper Actitis macularia

Gagnon L.-fairly common, on sandy shorelines. Rutledge L.-rare, on sandy lake shore. S. Taltson R.common, on sandy beaches. N. Taltson R.-common, on rocky beaches.

Greater Yellowlegs Totanus melanoleucus

Gagnon L.-fairly common, in muskegs. Rutledge L.-common in muskegs.

Lesser Yellowlegs Totanus flavipes

N. Taltson R.-scarce, near muskeg areas.

Least Sandpiper Erolia minutilla

Hjalmar L.-scarce, on sandy beach.
Parasitic Jaeger? Stercorarius parasiticus

N. Taltson R.-rare. This identification is not positive and it may have been Pomarine Jaeger. (Stercorarius pomarinus).

Herring Gull Larus argentatus

Gagnon L.-common. Rutledge L. - common, with several nesting sites on island. S. Taltson R.-common. N. Taltson R.-common. Whirlpool L.-common. Thekulthili L.-common.

California Gull Larus californicus

S. Taltson R.-fairly common, with nests on several islands.

Bonaparte's Gull Larus philadelphia

N. Taltson R.-fairly common, with nests on several islands.

Arctic Tern Sterna paradisaea

Gagnon L.-common, on islands. One colony, on a small island, contained 14 nests. Of the 14 nests, 11 contained three eggs each, 1 contained two eggs, and 2 contained one egg each. Whirlpool L.-fairly common. Thekulthili L.-common.

Hawk Owl Surnia ulula

Gagnon L.-rare, in a mature jack pine forest. Only one young bird was found with the adults, although an extensive search was made by the writers and George Watson, Canadian Wildlife Service, Ottawa.

Short-eared Owl Asio flammeus

N. Taltson R.-solitary, near lake shore.

Common Nighthawk Chordeiles minor Whirlpool L.-rare. Thekulthili L. - rare, observed near recently burned forests.

Yellow-shafted Flicker Colaptes auratus

N. Taltson R.-scarce, in birch forests. Whirlpool L.-rare. Thekulthili L.-rare.

Black-backed Three-toed Woodpecker Picoides arcticus

Gagnon L.-rare, in a recent burn. S. Taltson R.-rare, in mature forests. N. Taltson R.-rare, in mature forests.

Northern Three-toed Woodpecker Picoides tridactylus

Whirlpool L.-rare.

Tree Swallow Iriäoprocne bicolor Hjalmar L.-few, near muskegs.

Gray Jay Perisoreus canadensis

Gagnon L.-common, throughout area. Rutledge L.-common. S. Taltson R.-common. N. Taltson R.- 
common. Hjalmar L. - common. Whirlpool L.-common. Thekulthili L.-common.

\section{Common Raven Corvus corax}

Gagnon L.-rare. Rutledge L.common. S. Taltson R.-common. N. Taltson R.-common. Hjalmar L:common. Whirlpool L.-common. Thekulthili L.-common.

\section{Boreal Chickadee Parus hudsonicus}

S. Taltson R.-few. Whirlpool L.common. Thekulthili L.-common.

Robin Turdus migratorius

Gagnon L.-common. Rutledge L. -common. S. Taltson R.-common. N. Taltson R.-common. Hjalmar L. -common. Whirlpool L.-common. Thekulthili L.-common.

Hermit Thrush Hylocichla guttata Gagnon L.-common. Rutledge L. - common. S. Taltson R.-common. N. Taltson R.-common, in birch forests. Hjalmar L.-common. Whirlpool L.-common, in birch forests. Thekulthili L.-common.

Northern Shrike Lanius excubite.

N. Taltson R.-rare, with fledglings.

Myrtle Warbler Dendroica coronata Gagnon L.-common, throughout jack pine forests. Rutledge L.-common, in jack pine forests. S. Taltson R.-common, in jack pine forests. N. Taltson R.-common. Hjalmar L.common. Whirlpool L.-common.

Blackpoll Warbler Dendroica striata Rutledge L.-rare, in black spruce muskeg.

Red-winged Blackbird Agelaius phoeniceus

S. Taltson R.-rare, on a small lake near the river.

Rusty Blackbird Euphagus carolinus Whirlpool L.-rare.

Pine Grosbeak Pinicola enucleator Rutledge L.-rare, in mature black spruce forests.

Pine Siskin Spinus pinus

Whirlpool L.- rare, in black spruce forests.

Red Crossbill Loxia curvirostra

Gagnon L.-rare, in 40 year old jack pine forests.

Slate-colored Junco Junco hyemalis Gagnon L.-common, throughout area. Rutledge L.-common. S. Taltson R.-common. N. Taltson R.-common. Hjalmar L.-common. Whirlpool L.-common. Thekulthili L.common.

White-crowned Sparrow Zonotrichia leucophrys

Gagnon L.-rare, in white birch forests. Rutledge L-common. S. Taltson R.-common, in mature birch. Whirlpool L.-scarce. Thekulthili L. -scarce.

Fox Sparrow Passerella iliaca Whirlpool L.-rare.

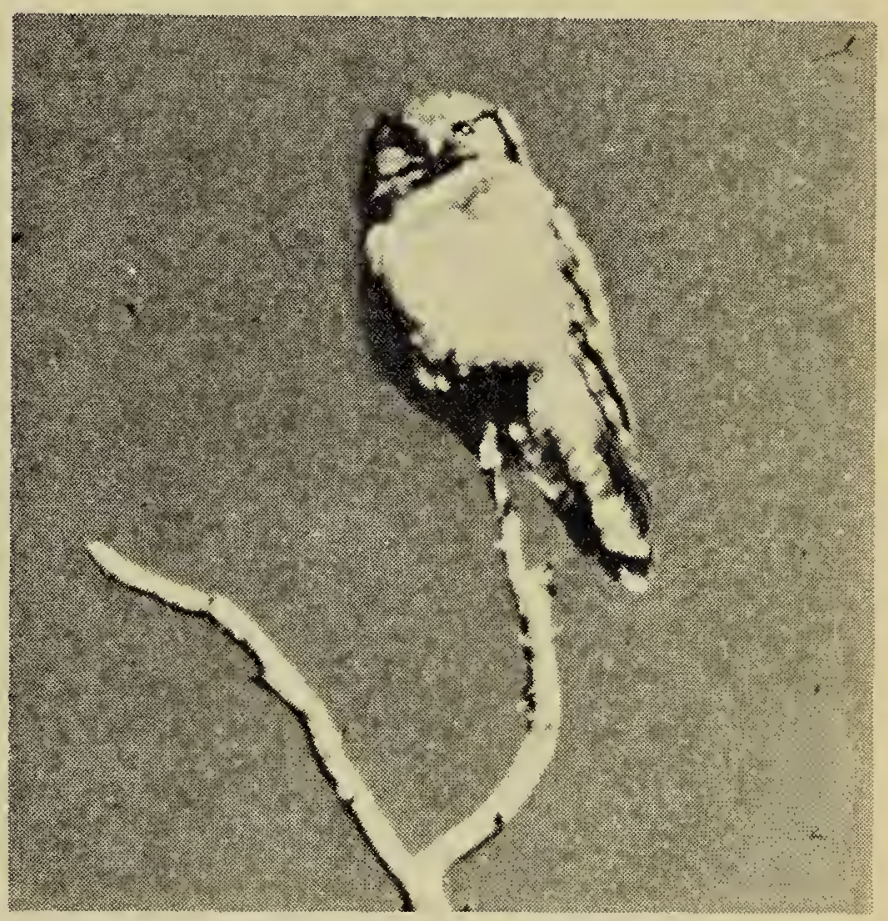

Hawk Owl

\section{LITERATURE CITED}

American Ornithologists' Union. 1957. The A.O.U. Check-list of North American Birds. Camsell, Charles, 1916. An exploration of the Tazin and Taltson Rivers, Northwest Territories. Geological Survey. Mémoir 84.

Harper, Francis, 1931. Physiographic and faunal areas in Athabaska and Great Slave Lake region. Ecology, 12:18-32.

Scotter, G. W. 1961. Summer observations of birds in northern Saskatchewan. Blue Jay, 19:70-74.

(Continued from Page 63)

sects you can take ( 2.5 milos $=2$ transects). 3. kind of vegetation along the transects. 4. Species of birds normaliy seen along the transests. 5. Do you have field glasses or binoculars? 6. Can you supply a good photograph of a typical part of the transects, and possibly some of the birds observed?

Results of the studies will be compiled and reported in the Blue Jay, with a paper intended at the end of two years.

Jan Looman, Experimental Farm, Swift Current, Sask.

\begin{tabular}{|l|}
\hline WANTED \\
WANTED TO PURCHASE- \\
pictures showing a brood of \\
fledged Screech Owls showing \\
gray and rufous phases.-Rand \\
McNally and Company, Box \\
7600, Chicago 80, Illinois, U.S.A. \\
\hline
\end{tabular}

